\title{
PREVALENSI TELUR Ascaris lumbricoides PADA KUKU DAN TINGKAT KEBERSIHAN PERSONAL PETUGAS KEBERSIHAN DI KRIAN, SIDOARJO
}

\author{
Prevalence of Ascaris lumbricoides's egg to fingernails and personal hygiene levels for \\ janitors at Krian, Sidoarjo
}
Erisa Listiany ${ }^{1}$, Acivrida Mega Charisma ${ }^{2}$, Elis Anita Farida ${ }^{3}$ ${ }^{1,2,3}$ STIKES RS Anwar Medika

Koresponden : acie.vrida@gmail.com/085855778561

\begin{abstract}
The infection of Ascaris lumbricoides in Indonesia is 66\% from 220 million people with one of the transmission by nail. This research aims to know prevalence of Ascaris lumbricoide's egg from nail and personal hygiene levels has to janitors at Krian, Sidoarjo. The type of research used descriptive survei with 25 respondent to examine their nails and questionnaire about their personal hygiene. The result was there found Ascaris lumbricoides's egg 3 respondent (12\%) from 25 respondent. The conclusion was prevalence of Ascaris lumbricoides's egg 3 respondent 12\% and their personal hygiene was bad like no handwash with soap after eat, no handwash with soap after poop, and no consumption a helminthic once every six month.
\end{abstract}

Keywords : Ascaris lumbricoides, nail, janitors

\begin{abstract}
ABSTRAK
Angka infeksi Ascaris lumbricoides di Indonesia sebanyak 66\% dari 220 juta penduduk dengan salah satu penularannya melalui kuku. Penelitian ini bertujuan untuk mengetahui prevalensi keberadaan telur cacing Ascaris lumbricoides dari sampel kuku dan tingkat kebersihan personal pada petugas kebersihan lingkungan daerah Krian, Sidoarjo. Jenis penelitian ini menggunakan survei deskriptif dengan 25 responden untuk diperiksa kukunya dan kuesioner terkait kebersihan personalnya. Hasil penelitian menunjukkan ditemukan adanya telur cacing Ascaris lumbricoides sebanyak 3 responden (12\%) dari 25 responden. Kesimpulan penelitian ini yaitu prevalensi telur cacing Ascaris lumbricoides sebanyak 3 responden (12\%) dan kebersihan personal mereka juga kurang baik seperti tidak mencuci tangan dengan sabun setelah makan, tidak mencuci tangan dengan sabun setelah buang air besar (BAB), dan tidak minum obat cacing tiap enam bulan sekali.
\end{abstract}

Kata kunci : Ascaris lumbricoides, kuku, petugas kebersihan

\section{PENDAHULUAN}

Infeksi cacing merupakan penyakit infeksi yang disebabkan oleh parasit cacing berbahaya yang ditularkan melalui tanah atau soil transmitted helminths (STH). Lumbricoides salah satunya Ascaris lumbricoides. Menurut Kamila et al. (2018) pada tahun 2015, angka infeksi tersebut di Indonesia sebanyak 66\% dari 220 juta penduduk tiap provinsi. Sedangkan daerah yang menunjukkan angka tertinggi yaitu di Sumatra (78\%), Sulawesi (88\%), Nusa Tenggara Barat (92\%), dan Jawa Barat $(90 \%)$.

Ascaris lumbricoides (cacing 
gelang) memiliki ukuran besar dan berwarna putih kecoklatan atau kuning pucat. Sedangkan morfologi telurnya yaitu berbentuk lonjong, memiliki kulit telur yang tidak berwarna dengan bagian luar tertutupi oleh lapisan albumin yang permukaannya bergerigi, berwarna coklat karena menyerap zat warna empedu dan bagian dalamnya terdapat selubung vitelin yang tipis, tetapi kuat sehingga telur Ascaris lumbricoides dapat bertahan di dalam tanah (Zulkoni, 2011). Adapun cara penularannya selain dari feses, dapat ditularkan melalui fecal oral yaitu dari kotoran kuku yang terkontaminasi oleh cacing tersebut (Souisa, 2019). Saat tubuh terinfeksi, cacing Ascaris lumbricoides hidup di dalam usus halus dengan mengambil sari-sari makanan sehingga mengakibatkan gangguan pada pencernaan dan gangguan aktifitas kerja bila kronis (Amran, 2017). Sehingga harus didasarkan pada aspek kebersihan personal yang baik.

Kebersihan personal yang tidak baik mencerminkan kondisi lingkungan dan perilaku individu yang tidak sehat. Pengetahuan penduduk yang masih rendah dan kebersihan yang kurang baik akan mudah terinfeksi cacing (Andaruni 2012). Seperti pada penelitian Ibrahim (2014) dilaporkan sebanyak 47 orang dari 122 (38.5\%) terinfeksi cacing STH diantaranya Ascaris lumbricoides yang sebanyak 41 orang (33.6\%), Trichiuris trichiura sebanyak 9 orang $(7.4 \%)$ dan hookworm hanya 1 orang $(0.8 \%)$ di kota Padang. Pada penelitian Dewi et al. (2018) juga melaporkan terdapat 8 responden $(33,33 \%)$ dari 24 responden pada sampel kuku petugas kebersihan pasar di kecamatan Mataram.

Dengan demikian, tujuan dari penelitian ini yaitu untuk mengetahui prevalensi keberadaan telur cacing Ascaris lumbricoides dari sampel kuku dan tingkat kebersihan personal pada petugas kebersihan lingkungan daerah Krian, Sidoarjo.

\section{METODE}

\section{Jenis penelitian, tempat dan waktu}

Jenis penelitian ini yaitu survei deskriptif dengan pemeriksaan sampel kuku untuk mengetahui keberadaan telur Ascaris lumbricoides dan pembagian kuesioner untuk mengetahui gambaran kebersihan personal pada petugas kebersihan lingkungan daerah Krian, Sidoarjo. Adapun pemeriksaan sampel kuku dilakukan di Laboratorium Biologi RS Anwar Medika. Penelitian ini dilakukan mulai bulan Maret- Juni 2020. Jumlah dan cara pengambilan subjek

Populasi subjek penelitian ini adalah petugas kebersihan lingkungan di daerah Krian, Sidoarjo yang berjumlah 50 orang dengan teknik pengambilan subjek secara random sampling dimana pengambilan subjeknya dilakukan acak dan masuk kriteria inklusi seperti petugas kebersihan lingkungan, tidak memakai APD, bersedia, dan mengisi kuesioner tentang kebersihan personalnya. Sehingga sampel diambil sebanyak 25 responden.

\section{Teknik Pengumpulan Data} data yaitu:

Adapun teknik pengumpulan

\section{Sosialisasi}

Sosialisasi pengambilan sampel kuku saat bekerja dan pembagian kuesioner pada petugas kebersihan.

2. Pemeriksaan sampel kuku (Ideham dan Dachlan, 2019)

Metode pemeriksaan ini adalah pewarnaan menggunakan eosin $2 \%$. Alat dan bahan yang digunakan meliputi: $\mathrm{NaCl}$ 0,9\%, Etanol 95\%, Eosin 2\%, alkohol swab, handscoon, masker, mikroskop binokuler, kaca objek, spatula, kaca penutup, tabung reaksi, rak tabung reaksi, sentrifuse, dan pot sampel. 
Prosedur kerja: sampel kuku yang di rendam dengan nacl $0.9 \%$ selama 20 menit dan sentrifuse kecepatan 2500 rpm selama 5 menit kemudian saring dengan kasa. Kaca objek yang telah dibersihkan dengan etanol 95\% diteteskan sedimen sampel lalu eosin $2 \%$ sebanyak 1-2 tetes dan diratakan membentuk lingkaran kemudian tutup dengan kaca penutup. Setelah itu dilakukan pengamatan pada mikroskop dengan pembesaran 40x.

3. Pengumpulan kuesioner

Adapun isi kuesioner yang diisi oleh petugas kebersihan yaitu tentang kebersihan personal yang terkait dengan kebiasaan mencuci tangan dengan sabun, mencuci tangan dengan sabun setelah BAB, memotong kuku seminggu sekali, dan minum obat cacing tiap enam bulan sekali.

\section{Pengolahan Data}

Data yang diperoleh di kumpulkan dan dihitung prevalensi dibawah ini:

$$
\frac{\text { jumlah positif telur cacing }}{\text { jumlah seluruh sampel }} \times 100 \%
$$

Kemudian diolah dalam bentuk tabel yang berisi frekuensi dan persentase.

\section{HASIL}

Hasil penelitian ini terbagi menjadi dua yaitu hasil pemeriksaan kotoran kuku dan hasil pengisian kuesioner tentang kebersihan personal dari petugas kebersihan.

Hasil pemeriksaan kotoran kuku pada tabel 1 menunjukkan dari 25 sampel ditemukan keberadaan telur Ascaris lumbricoides sebanyak 3 sampel (12\%) sedangkan 22 sampel (88\%) tidak ditemukan keberadaan telur cacing Ascaris lumbricoides. Kemudian hasil pengisian kuesioner tentang kebersihan personal (tabel 2) dari petugas kebersihan menunjukkan sebanyak 25 responden yang yang tidak memiliki kebiasan cuci tangan dengan sabun sebanyak 13 responden (52\%), yang tidak memiliki kebiasaan cuci tangan dengan sabun setelah BAB sebanyak 16 responden $(64 \%)$, yang tidak memiliki kebiasaan memotong kuku seminggu sekali sebanyak 7 responden (28\%), dan yang tidak memiliki kebiasaan minum obat cacing tiap enam bulan sekali sebanyak 24 responden (96\%). Sedangkan yang memiliki kebiasaan cuci tangan dengan sabun sebelum makan sebanyak 12 responden (48\%), kebiasaan cuci tangan dengan sabun setelah BAB sebanyak 9 responden (36\%), kebiasaan memotong kuku seminggu sekali sebanyak 18 responden (72\%), kebiasaan minum obat cacing tiap enam bulan sekali hanya 1 responden (4\%).

\section{PEMBAHASAN}

Prevalensi telur Ascaris lumbricoides dari sampel kuku petugas petugas kebersihan sebanyak $12 \%$. Hal ini dikarenakan petugas kebersihan selalu kontak dengan kondisi lingkungan kurang baik dimana lingkungan tersebut adalah tempat perkembangbiakan telur Ascaris lumbricoides yang dapat hidup lama dan tahan terhadap kondisi buruk. Selain itu, kebersihan personal juga perlu diperhatikan.

Berdasarkan hasil pengisian kuesioner tentang kebersihan personal dari petugas kebersihan ternyata kebersihan personal mereka kurang baik seperti tidak mencuci tangan dengan sabun sebelum makan, tidak mencuci tangan dengan sabun setelah $\mathrm{BAB}$, dan tidak minum obat cacing tiap enam bulan sekali. Sehingga persentase kebersihan personal yang kurang baik menunjukkan hasil lebih besar daripada kebersihan personal yang baik. Hal ini sesuai dengan penelitian Tirtayanti et al. (2016) bahwa tingginya prevalensi keberadaan 
telur cacing Ascaris lumbricoides juga diikuti oleh tingginya prevalensi kebiasaan cuci tangan yang buruk dan penggunaan pelindung tangan yang buruk pada pengrajin genteng di Tabanan. Penelitian Herdiansyah (2019) juga melaporkan bahwa kebersihan personal yang kurang baik berpeluang munculnya telur cacing Ascaris sebanyak 23,3\% pada sampel kuku nelayan di Pangandaran. Menurut Charisma, dkk (2020) responden yang tidak mempunyai kebiasaan mencuci tangan menyebabkan telur atau larva cacing yang menempel pada tangan atau kuku dapat masuk melalui makanan atau masuk tanpa perantara jika responden memasukkan tangan pada mulut.

\section{KESIMPULAN}

Kesimpulan dari penelitian ini yaitu prevalensi keberadaan telur cacing Ascaris lumbricoides pada sampel kuku petugas kebersihan sebanyak $12 \%$ yang ternyata kebersihan personal mereka kurang baik seperti tidak mencuci tangan dengan sabun setelah makan, tidak mencuci tangan dengan sabun setelah $\mathrm{BAB}$, dan tidak minum obat cacing tiap enam bulan sekali.

\section{SARAN}

Saran untuk penelitian ini yaitu perlu dilakukan promosi kesehatan secara rutin oleh dinas kesehatan maupun dinas kebersihan kabupaten mengenai kebersihan personal, sebaiknya petugas kebersihan juga lebih memperhatikan terkait kebersihan personal guna mencegah terkontaminasi telur cacing masuk ke mulut, dan perlu dilakukan penelitian lanjutan mengenai pemeriksaan kuku terhadap keberadaan telur cacing STH yang lain seperti hookworm, dan pemeriksaan pada sampel feses terkait keberadaan telur cacing Ascaris lumbricoides.

\section{UCAPAN TERIMA KASIH}

Peneliti

mengucapkan terimakasih kepada STIKES RS Anwar Medika, petugas kebersihan lingkungan daerah Krian kabupaten Sidoarjo yang telah berpartisipasi, dan pihak-pihak terkait yang telah membantu serta mendukung dalam penelitian ini.

\section{DAFTAR PUSTAKA}

Amran, P. 2017. Prevalensi Penyakit Kecacingan dan Hubungannya dengan Anemia pada Anak Sekolah Dasar yang ada di Kota Makasar. Jurnal Media Analis Kesehatan, 08(02): 59-66.

Charisma, A. M., Farida, E. A., Wahyuni, K. I., \& Dewi, Y. E. N. K. 2020. Prevalensi Telur Cacing Nematoda Usus Soil Transmited Helmint (Sth) Dengan Metode Konsentrasi Pada Siswa Mi Sunan Ampel 1 SidorogoTrosobo Kecamatan Taman Kabupaten Sidoarjo Provinsi Jawa Timur. Journal of Pharmaceutical Care Anwar Medika (J-PhAM), 2(2), 1-12.

Dewi et al. 2018. Investasi Kecacingan pada Petugas Kebersihan Pasar di Kecamatan Mataram dan Kecamatan Cakranegara. Jurnal Analis Medika Bio Sains, 05(01): 33-39.

Herdiansyah, D dan Santoso, S. S. 2019.

Analisis Kebersihan Diri terhadap Keberadaan Telur Cacing Ascaris pada Kuku Nelayan Desa Batu KarasCijulang Pangandaran. Jurnal Kedokteran dan Kesehatan, 15(01): 94-103.

Ideham, B dan Dachlan, Y. P. 2019. Penuntun Praktis Parasitologi Kedokteran. Airlangga University Press.

Kamila, et al. 2018. Hubungan Kecacingan Dengan Status Gizi 
Dan Prestasi Belajar Pada Anak Sekolah Dasar Kelas IV Dan V Di Kelurahan Bandarharjo Semarang. Journal of Nutrition College, 7(2): 77-82.

Soleman, et al. 2014. Hubungan Personal Hygiene dengan Penyakit Cacingan pada Pekerja Pengangkut Sampah di TPA Sumompo Kota Manado tahun 2013. Jurnal Kesehatan Lingkungan, 03(02): 01-05.

Souisa, G. V., dkk. 2019. Identifikasi Telur Cacing pada Kuku dan Personal Hygiene Peserta Didik di Sekolah Dasar. Jurnal 2-Trik: Tunas-Tunas Riset Kesehatan, 09(03): 216-220.

Tirtayanti, et al. 2016. Identifikasi Telur Cacing Nematoda Usus pada Kuku Tangan Pengrajin Genteng di Desa Pejaten, Kediri, Tabanan.
Meditory: The Journal of Medical Laboratory, 04(02): 109-116.

Zulkoni. 2011. Parasitologi untuk Keperawatan, Kesehatan Masyarakat. Yogyakarta: Nuha Medika. 
Tabel 1

Hasil Pemeriksaan Kotoran Kuku Petugas Kebersihan Lingkungan Krian, Sidoarjo

\begin{tabular}{lcc}
\hline \multirow{2}{*}{ Hasil } & \multicolumn{2}{c}{ Jumlah Keberadaan Telur Cacing } \\
\cline { 2 - 3 } & $\mathbf{N}$ & $\mathbf{\%}$ \\
\hline Positif & 3 & 12 \\
\hline Negatif & 22 & 88 \\
\hline
\end{tabular}

Tabel 2

Distribusi Frekuensi Kebersihan Personal Petugas Kebersihan Lingkungan Krian, Sidoarjo

\begin{tabular}{lcc}
\hline \multicolumn{1}{c}{ Kategori Kebersihan Personal } & n & $\%$ \\
\hline 1. Kebiasaan cuci tangan dengan sabun sebelum makan & 12 & $48 \%$ \\
Ya & 13 & $52 \%$ \\
Tidak & 9 & $36 \%$ \\
\hline 2. Kebiasaan cuci tangan dengan sabun setelah BAB & 16 & $64 \%$ \\
Ya & & \\
Tidak & 11 & $44 \%$ \\
\hline 3.Kebiasaan menggunakan alas kaki saat membersihkan & 14 & $56 \%$ \\
sampah & & \\
Ya & & \\
Tidak & 18 & 72 \\
\hline 4. Kebiasaan memotong kuku seminggu sekali & 7 & $28 \%$ \\
Ya & & \\
Tidak & 1 & $4 \%$ \\
\hline 5. Kebiasaan minum obat cacing 6 bulan sekali & 24 & $96 \%$ \\
Ya &
\end{tabular}

